IZA DP No. 5019

From Classroom to Wedding Aisle: The Effect of a Nationwide Change in the Compulsory Schooling Law on Age at First Marriage in the UK

Nattavudh Powdthavee

Kampon Adireksombat

June 2010 


\title{
From Classroom to Wedding Aisle: The Effect of a Nationwide Change in the Compulsory Schooling Law on Age at First Marriage in the UK
}

\author{
Nattavudh Powdthavee \\ Nanyang Technological University \\ and IZA
}

Kampon Adireksombat

Siam Commercial Bank

Discussion Paper No. 5019

June 2010

IZA

P.O. Box 7240

53072 Bonn

Germany

Phone: +49-228-3894-0

Fax: +49-228-3894-180

E-mail: iza@iza.org

Any opinions expressed here are those of the author(s) and not those of IZA. Research published in this series may include views on policy, but the institute itself takes no institutional policy positions.

The Institute for the Study of Labor (IZA) in Bonn is a local and virtual international research center and a place of communication between science, politics and business. IZA is an independent nonprofit organization supported by Deutsche Post Foundation. The center is associated with the University of Bonn and offers a stimulating research environment through its international network, workshops and conferences, data service, project support, research visits and doctoral program. IZA engages in (i) original and internationally competitive research in all fields of labor economics, (ii) development of policy concepts, and (iii) dissemination of research results and concepts to the interested public.

IZA Discussion Papers often represent preliminary work and are circulated to encourage discussion. Citation of such a paper should account for its provisional character. A revised version may be available directly from the author. 
IZA Discussion Paper No. 5019

June 2010

\section{ABSTRACT \\ From Classroom to Wedding Aisle: The Effect of a Nationwide Change in the Compulsory Schooling Law on Age at First Marriage in the UK ${ }^{*}$}

Does more schooling causes a delay in marriage? Using a nationwide change in the compulsory schooling law in the UK as a source of exogenous variation in education, this paper estimates the causal effect of schooling on age at first marriage. The 1947 reform, which uniquely affected about a half of the relevant population, led to a jump in the average age at first marriage for both genders, with the effect being much more statistically robust for men than women. The regression discontinuity and IV estimates imply that completing an extra year of schooling increases the average age at first marriage by approximately 3 years for men and almost 2 years for women. Given the compelling effect of the 1947 reform, it is likely that our reduced form estimates come close to mirroring the ATE for the general population.

JEL Classification: $\quad$ 12, J12, N34

Keywords: compulsory schooling, age at first marriage, regression discontinuity, human capital, family formation

Corresponding author:

Nattavudh Powdthavee

Division of Economics

School of Humanities \& Social Sciences

Nanyang Technological University

14 Nanyang Drive

Singapore, 637332

E-mail: np517@york.ac.uk

\footnotetext{
*We thank Paul Devereux and Shelly Lundberg for their useful comments. All usual disclaimers apply.
} 


\section{Introduction}

It is known from cross-sectional studies (Oppenheimer, 1997; Goldstein \& Kenney, 2001; Raymo, 2003; Wong, 2005; Worner, 2007) that highly educated individuals tend to marry significantly later than those with lower qualifications. Yet this is not a persuasive reason to believe that more education causes a delay in the timing of the first marriage. Because their causal implications are hard to interpret, cross-section relationships are only suggestive. Indeed, one approach is to argue that, in countries where married men's labor force participation are greater than single men's, male education will result in early marriages simply because these men will want to make the most of specialization in the market (Becker, 1973).

To make persuasive empirical progress on this issue, an exogenous variation in the level of educational attainment - preferably on a large scale - is required to gauge the causal impacts of education on the timing of first marriage. The current study does this by exploring how a 'natural experiment' in the form of an education act - i.e. a nationwide change in the compulsory schooling law from aged 14 to 15 in April $1^{\text {st }} 1947$, which affected almost everyone in England and Wales who would have left school at age 14 prior to 1947 - affected the distribution of age at first marriage in the post-World War II UK. ${ }^{2}$

Section 2 provides the paper's motivations and an account of previous empirical evidence on the causal effects of schooling on age at first marriage. Section 3 presents a brief introduction to the 1944 Education Act in the UK. Data and empirical strategy are discussed in Section 4. Section 5 presents the estimates. Section 6 concludes.

\footnotetext{
${ }^{2}$ The economic literature is dominated by studies that examined the effects of compulsory schooling on wages and health. For the literature on the effect of compulsory schooling on wages, see, e.g., Harmon \& Walker, 1995; Oreopoulos, 2006, 2007; Devereux \& Hart, 2010. For the literature on the effect of schooling on health outcomes, see, e.g., Adams, 2002; Spasojevic, 2003; Lleras-Muney, 2005; Clark \& Royer, 2008; Siles, 2009; Jürges, Kruk, \& Reinhold, 2010; Powdthavee, 2010).
} 


\section{Motivations and Previous Literature}

Why should economists care about the determinants of age at first marriage? First, there is evidence that married men earn ceteris paribus more in the labor market compared to single men (Korenman \& Neumark, 1991; Loe, 1996). For women, marriage has been found to reduce labor force participation, as well as leaving wages unchanged (Korenman \& Neumark, 1992). Secondly, according to Coale (1971), age at first marriage is considered an important determinant of fertility in most industrialized countries, which is a topic of much interest to economists and policy makers. Third, a rising age in marriage may be socially undesirable for men, considering that marriage has been shown empirically to have considerable protective effects on men's health and longevity. For example, Jonathan Gardner and Andrew Oswald (2004) found married people to live approximately 6-percentage-points longer than their single counterpart. One explanation for this is that marriage encourages healthy types of behaviors, and discourages risky and unhealthy ones such as smoking, drinking and other substance abuse. In addition to this, marriage makes risk-sharing within household possible (Ermisch, 2003) and the presence of a spouse makes it more likely that the individual will receive both physical and emotional supports in times of illness and depression (see, e.g., Powdthavee, 2009). However, it is also known from the literature that early marriage increases the chances of divorce (Moore and Waite, 1981; Martin and Bumpass, 1989).

Theoretically, the overall effect of schooling on age at first marriage is a priori unclear. According to Gary Becker's (1973) model of specialization in which partners can potentially gain higher welfare through a division of labor, increased education should open 
up economic alternatives to getting married for women ${ }^{3}$, leading to a delaying effect of female education on the timing of marriage (see also Keeley, 1979; Klaauw, 1996). However, the effect should be different for male education. For men, increased education should be observed with early marriages simply because these men profit most from a marriage with a traditional division of labor and an increase in human capital should also improve men's efficiency in their search for a potential spouse (Keeley, 1979). By contrast, Matsushita (1989) and Brüderl and Diekman (1997) argued that there may also be an enrolment or institutional effect of education on the timing of marriage, in that more years spent in fulltime education imply a delay in the family formation for both genders. This institution effect can be explained by the hypothesis that (i) students are not ready for adult roles, (ii) school demands much more time that is not available for other roles, and (iii) there are normative expectations that married people should be financially secured (Thornton, Axinn, \& Teachman, 1995; Koball, 1998). Adam Isen and Betsey Stevenson (2010) proposed that the recent shift from Beckerian model of production-based marriage to consumption-based marriage - i.e. a marriage that is based on consumption complementarities between husband and wife - may make marriage more appealing to those with higher disposable incomes. And since education is a reasonable proxy for higher life-time earning, people who prefer consumption-based marriage are thus likely to invest more in human capital and, consequently, choose to delay their marriage.

In addition to the theoretical difficulty at predicting the overall impact of education on age at first marriage, there are also a variety of sources of bias which may be associated with the empirical estimation of the schooling effect on the timing of family formation. For example, causality may run in reverse from early marriage to less schooling (see, e.g., a seminal study by Erica Field and Attila Ambrus (2008) on the causal effect of age of

\footnotetext{
${ }^{3}$ However, this assumption may not hold if women in a society have fewer favorable career prospects than men and are generally paid less (for a comprehensive review on the subject, see Brüderl and Diekman, 1997).
} 
menarche on female education in Bangladesh), which implies that estimates of the schooling effect on age at first marriage may be biased upward. Secondly, there may be omitted third variables such as ability, personality traits, and social trends that are unobserved and yet influence both schooling and the timing of marriage. A third source of bias is measurement error, which can impose a severe negative bias on the estimated schooling effect (Blackburn and Neumark, 1995).

Empirical evidence on the causal links between education and the timing of marriage is scarce. Of the few notable examples, Lucia Breierova and Esther Duflo (2004) addressed the endogeneity problem by using time and region varying exposure to the school construction program in Indonesia to generate instrumental variables for the average years of education in the household, and the difference in education between husband and wife. They found average education to have a positive and statistically significant impact on female's age at first marriage - i.e. education helps delay the timing of first marriage. The effect is also stronger for female education than male education.

Vegard Skirbekk, Hans-Peter Kohler, and Alexia Prskawetz (2004) applied exogenous variations in the age at school graduation (i.e. children who were born in two consecutive months, December and January, belong to two different school cohorts and graduate in two different calendar years) to study the effects of education on age at first marriage in Sweden. Within a birth cohort, they found women who were born in January are, on average, 2.1 months older when they marry for the first time than are women who were born in December.

Using the extension of compulsory schooling law in Turkey, Murat Kirdar, Meltem Dayığlu Tayfur and İsmet Koç (2009) estimated a duration model of the effect of education on the probability of marriage among young women. They found the effect of a change in the 
compulsory schooling law at the very young age (i.e. a raising of school leaving age from 5 to 8 in 1997) is to reduce the proportion of marriage at age between 10-17 years old from $15 \%$ to $10 \%$.

In a heavily technical paper, Paul Devereux and Gautam Tripathi (2009) examined the effect of compulsory schooling on age at first marriage in the US. By combining censored i.e. young people who are not yet married in the data - and uncensored data sets, a GMM model was estimated and the authors concluded that moving from less than 9 years of compulsory schooling to 9 years raises age at first marriage by approximately $1 \%$. The effects for 10 years compulsory schooling is $1.3 \%$, and the effects of 11 years is around $2 \%$.

One important issue concerning the natural experiment and instrumental variables (IV) approaches adopted by previous work is that the only effect we can be sure that this method estimates is the local average treatment effect (LATE), i.e. the average treatment effect (ATE) among those who alter their status because they react to the policy or the instrument (Imbens and Angrist, 1994). Perhaps with an exception of Kirdar et al. (2009), the instruments used in the age at first marriage literature only apply to a small fraction of the population. ${ }^{4}$ What this implies is that their IV estimates will only approximate the ATE among a small and peculiar group rather than the general population, whereas OLS estimates, in the absence of omitted third variables and measurement error problems, approximate ATE among everyone (Angrist and Kruger, 1991; Card, 2001). For example, as in the aforementioned study by Breierova and Duflo (2003), because school constructions in Indonesia took place randomly and by districts, it is possible that their IV estimates only approximate the average treatment effects among students who happened to be residing in

\footnotetext{
${ }^{4}$ The main difference between the current study and Kirdar et al.'s, other than the dataset itself, is the dependent variable. Whilst Kirdar et al. (2009) used a dummy variable that takes a value of 1 if the person is married between aged 10 and 17 and 0 otherwise, our study relies on a continuous age at first marriage as the main dependent variable.
} 
these districts when the changes took place. The same also applies to Devereux and Tripathi (2009) where only a very small proportion of people are affected by the US law changes.

Perhaps one of the more successful instruments used to estimate the causal effects of education in the economics literature which, when implemented, will produce the IV estimate that is closest to the ATE for the general population as possible, is the change in the UK compulsory schooling law from aged 14 to 15 in 1947 (see Harmon and Walker, 1995; Oreopoulos, 2006). One reason for this is simply because the introduction of the minimum school-leaving age in the UK for the first time in April $1^{\text {st }}, 1947$ affects a large fraction of the population - i.e., approximately half of the relevant individuals - who would have left school at age 14 prior to 1947 . The dramatic effect of the introduction of such a law on the amount of schooling received by the general population means that the estimated LATE of education will come close to mirroring population ATE (Oreopoulos, 2006). We follow Harmon and Walker (1995) and Oreopoulos (2006) before us and use the same 1947 reform to estimate (i) a regression discontinuity model and (ii) and IV model of the causal effect of schooling on age at first marriage in the UK.

\section{A brief history of the Education Act 1944}

In an attempt to generate more skilled labor force in the UK, the Conservative politician Lord Butler proposed the Education Act 1944 to the members of the parliament which included the introduction of the Tripartite system of secondary education (e.g., forming three types of schooling, namely: grammar school, secondary technical school, and secondary modern

school), free secondary education for all, and the raising of the school leaving age from 14 to 15. Although the act should have been brought into effect as from September 1939, it was not implemented because of the effects of the World War II. This led to a delay until April $1^{\text {st }}$ 
1947 when it was eventually introduced as part of the new Ministry of Education's plan (Wallace, 1981).

One of the effects of the act, namely the raising of the school leaving age, was that persons born before April $1^{\text {st }} 1933$ faced a minimum school-leaving age of 14 , and persons born from April $1^{\text {st }} 1933$ faced a minimum school-leaving age of 15 . While this provided an extra year of schooling for those born from April $1^{\text {st }} 1933$, very few impacted students stayed on until 16 to take state exams and acquire a credential. The change was also accompanied by an increase in the number of teachers, buildings, and furniture to accommodate the rapid increase in the numbers of students who now had to stay in school because of the law (for more background of the law, see Oreopoulos, 2006; Clark \& Royer, 2008).

The law in 1947 had a significant effect on the level of schooling for the impacted. Using the General Household Survey, Oreopoulos (2006) reports a fall in the fraction of persons leaving school at 14 from $57 \%$ in 1946 to $30 \%$ in 1947, and to less than $10 \%$ in over three years. Clark and Royer (2008) also reports a similar drop in the proportion of 14-years old school leavers using the Health Survey for England.

\section{Data and empirical strategy}

\section{A. Data}

The data in this study comes from the British Household Panel Survey (BHPS). This is nationally representative of British households, which has been conducted between September and Christmas of each year from 1991 (Taylor et al., 2002). We focus our analysis on Waves 2, which was conducted in 1992. In this survey wave, which is the one that 
provides detailed information on marital history, the BHPS asks randomly selected individuals the following two questions about their marriage:

(1) In what year did you marry?

(2) What is the sequence number of most recent marriage?

Our empirical category AGE AT FIRST MARRIAGE, which is a continuous variable, is derived from subtracting year of marriage from the first marriage (i.e. marriage sequence $=1$ ) by the respondent's year of birth. For our schooling variable, we use school leaving age as a proxy for years spent in full-time education. This is a continuous variable which is recorded once for each individual in the BHPS.

Our analysis uses Wave 2 of the BHPS, which originally consists of 8,918 adults (i.e. aged 16 and over) residing in England and Wales. Of those, 1,571 women and 1,398 men are born between 1921 and 1946, which are the cohorts of interest. From the 1921-1946 cohorts, 1,453 women (i.e. $92 \%$ ) and 1,227 men (i.e. $88 \%$ ) had been married at least once and have recorded some information regarding the age left full-time education, suggesting that the age at first marriage variable is observed for the majority of people in our selected cohorts. ${ }^{5}$ This forms our main sample. Since previous studies have shown education to have differential impacts on wages, health, and the timing of marriage by gender (see, e.g., Breierova \& Duflo, 2004; Devereux \& Hart, 2010; Powdthavee, 2010), we also conduct our analysis separately for men and women. A summary of descriptive statistics is given in Table A1 of the appendix.

The legislation on changing the minimum school-leaving age from 14 to 15 in England and Wales was introduced in the 1944 Education Act, with the eventual increase

\footnotetext{
${ }^{5}$ Since our natural focus is on the older cohorts, we do not face the same censoring problem of whether or not to include young people who are not yet married in the analysis (see Devereux and Tripathi, 2009).
} 
implemented nationwide in 1947. Figures $1 \& 2$ plot the fractions of school leavers at age 14 before and after the 1947 reform for men and women respectively. Similar to Oreopoulos (2006) and Clark and Royer (2008), we can see from both figures that a very high fraction of men and women in the BHPS left school before 1947. For men, the implementation of the law in 1947 results in a sharp drop in the fraction of school leavers at 14 from $62 \%$ in 1946 to $19 \%$ in 1947 . For women, the fraction of school leavers at 14 fell from $59 \%$ in 1946 to $23 \%$ in 1947. Over the course of three years between 1947 and 1949, the fraction of school leavers at 14 fell from $19 \%$ to $2 \%$ for men and $23 \%$ to $7 \%$ for women.

\section{B. Empirical Strategy}

This paper adopts two econometric models to estimate the compulsory schooling effects on the timing of marriage: regression discontinuity (RD) and instrumental variables (IV). Following Imbens and Lemieux (2008), our so-called "fuzzy" RD design ${ }^{6}$ involves estimating two separate global polynomial equations:

$$
\begin{aligned}
& S_{i}=\beta_{0}+\beta_{1} L A W_{i}+f\left\{Y O B_{i}\right\}+\varepsilon_{i} \\
& F M_{i}=\gamma_{0}+\gamma_{1} L A W_{i}+g\left\{Y O B_{i}\right\}+\xi_{i}
\end{aligned}
$$

Here, $i$ indexes individuals, $S$ represents age left full-time education; FM denotes age at first marriage; LAW is a dummy variable that takes a value of 1 if the person was 14 from April $1^{\text {st }} 1947$ (i.e. born from April $1^{\text {st }} 1933$ ) and zero otherwise; both $f\left\{Y O B_{i}\right\}$ and $g\left\{Y O B_{i}\right\}$ are quartic functions of birth year. Both equations are clustered by birth year.

\footnotetext{
${ }^{6}$ Because some individuals left school at younger ages than the legal school leaving age, we have here a fuzzy $\mathrm{RD}$ design, i.e. the probability of receiving the treatment needs not change from 0 to 1 at the threshold.
} 
Least squares estimation of (1) and (2) will generate $\beta_{1}$ and $\gamma_{1}$, which represent the effect of compulsory schooling on school leaving age and age at first marriage respectively. These estimates signify the "jump" in both education and the timing of marriage associated with being 14 after the date of the reform, and the ratio of the estimates $\left(\gamma_{1} / \beta_{1}\right)$ will give the standard IV Wald estimator, which is also a local average treatment effects (LATE) estimate (see Oreopoulos, 2006).

An alternative strategy is to estimate the LATE using a standard IV approach. Here, the identification is achieved by the inclusion of the LAW variable in the first-stage regression (see equation (1) above). The predicted age left full-time education is then used as the excluded instrumental variable in the age at first marriage equation. Again, all IV equations include a quartic function of birth year as controls and are clustered by birth year. Because of the cross-section nature of our BHPS sample - i.e. each person appears in our sample only once - age is almost perfectly collinear with year of birth. This implies that there is no need to control for age of the respondent in the estimation.

\section{The effects of 1947 reform on the timing of first marriage}

\section{A. OLS Results}

Table 1 reports OLS estimates on the relationship between age at first marriage and age left full-time education by gender. The OLS specification uses individual-level data and regress age at first marriage on age left full-time education and a quartic function of birth year. Using native cohorts from England and Wales born between 1921 and 1946 in the BHPS, OLS produces an estimated coefficient on age left full-time education of 0.759 for men and 0.987 for women and both are statistically significant at the $1 \%$ level. 


\section{B. First-Stage Schooling Regressions}

Table 2 calculates the first-stage schooling estimates by regressing mean age at first marriage on a quartic function of birth year and a dummy variable for the minimum school-leaving age at 15. All regressions are clustered by birth year. As can be seen from Column 1, the law has led to an increase in the average school-leaving age in the BHPS by approximately 0.7-year for men and 0.5 -year for women. Both of these effects are statistically significant at the $1 \%$ level.

To illustrate these first-stage effects, Figures $4 \& 5$ plot for men and women the mean age left full-time education by the year cohorts were aged 14, using individuals who were born between 1921 and 1947 in the BHPS. The vertical line indicates the year after which the cohorts faced the minimum school-leaving age of 15. As we can see from both figures, the jump in mean educational attainment in 1947 is very clear, suggesting that the law has been very successful at raising the level of education for both men and women.

\section{Reduced-Form Effects}

We report the reduced form estimates in Column 2 of Table 2. The results differ between men and women. For men, the reduced form estimate of the effect of the law on age at first marriage is $2.565(0.645)$, which means that the law raises the average age at first marriage by approximately two years and six months. For women, the law increases the average age at first marriage by approximately six months, i.e. 0.683 , but the effect is statistically insignificant at any conventional levels, suggesting a very small effect of the law change on the timing of marriage for women. This is consistent with Devereux and Hart (2008) and 
Powdthavee (2010) who found the reduced form effects on wages and health to be statistically significant only for men and not for women. The ratio of the two coefficients (= $\gamma / \beta$ ), which is equivalent to the IV Wald estimate or the LATE estimate, is $2.565 / 0.746=$ 3.438 years for men and $0.683 / 0.526=1.298$ years for women. Hence, an extra year of exogenous full-time education leads to men and women delaying their first marriage by 3.4 years and 1.3 years respectively.

Figures $6 \& 7$ display the age at first marriage estimates graphically. While the age at first marriage falls monotonically for the early cohorts, which seems to suggest that there is a downward social trend in the age at first marriage in the post-WWII $\mathrm{UK}^{7}$, there is a clear jump in the average age at first marriage for both genders when the law was implemented in 1947. However, the break is evidently much larger for men than for women.

\section{Conventional IV Estimates}

Column 3 of Table 2 moves to the conventional instrumental variables (IV) analysis. Using the change in the minimum school-leaving age law in 1947 as the instrumental variable, the estimated IV coefficients are similar in size to what had been calculated in the RD analysis. For men, one more year of full-time education leads to an increase in the age at first marriage by approximately 3.4 years compared to 0.8 year obtained by OLS (see Table 1), suggesting the presence of a large and negative bias in the observed cross-sectional relationship between schooling and age at first marriage. For women, the estimated IV coefficient is very similar to the one obtained by OLS, although it is not statistically significant at any conventional levels.

\footnotetext{
${ }^{7}$ The higher average age at first marriage among the older cohorts is partly explained by the fact that a lot of young men in their early 20s were sent off to war (World War II, 1939-1945), which means that people who were born in the late 1920s would not have been married before the war began and may not get to marry until after the war was over. The fall in the age at first marriage for later cohorts is also consistent with the US and European evidence of a falling average age at first marriage that followed immediately at the end of WWII, i.e. the Baby Boom period (see, e.g., Glick, 1977).
} 
Since the RD design implies that we cannot make causal inferences about the treatment effect away from the discontinuity, Table 3 checks the robustness of Table 2's results by restricting the original sample by almost half - from cohorts born in 1926 to those born in 1939. Reducing bandwidth results produces the first stage effect of $0.587(0.160)$ for men and $0.684(0.093)$ for women. As for the reduced form effect, the effect of the law is to raise the age at first marriage for men by 1.743 and for women by 1.385 years, both of which are statistically significant at the $5 \%$ level. These figures imply that LATE is approximately 3 years for men and 2 years for women, which in terms of magnitudes are statistically indistinguishable to what had been obtained previously in Table $2 .^{8}$ In addition to this, the positive and statistically significant reduced form effect in the smaller female sub-sample is consistent with Figure 6's noticeable "break" in the average women's age at first marriage in 1947, which suggests that the law may have been successful at increasing age at the first marriage for marginal women.

Up to this point, our main focus has been the estimation of the effect of compulsory schooling on the age of first marriage. Such an approach seems to be of some worth in its own right. However, in order to make further justification on the importance of education on the timing of marriage, Table 4 presents the reduced form and IV estimates on the effect of education on the respondent's age at the birth of his or her first child. One hypothesis is that education will not impact the timing of fertility beyond its impact on the timing of marriage given that the two variables are likely to be strongly correlated - i.e. age at first marriage should be a strong predictor of age at first child (Coale, 1971).

The dependent variable is derived from the "What is the year of birth of your natural child?" variable taken from Wave 2 of the BHPS. The AGE AT FIRST CHILD, which is a

\footnotetext{
${ }^{8}$ Another common robustness check would be to include age polynomial as controls in the age at first marriage equation. This is not possible, however, given that age and cohort are perfectly collinear in cross-section regressions.
} 
continuous variable, is calculated from subtracting year of birth of the oldest natural child (dead or alive) by the respondent's year of birth. Conditioning on having been married at least once, we can see from Column 1 that the law has resulted in men delaying having their first child by approximately 1.8 years, on average. The effect is also statistically significant at the $1 \%$ level. For women, the effect of the law on the age at the birth of first child is also positive but statistically insignificantly different from zero.

Is the effect of compulsory schooling on the timing of fertility independent from its effect on the timing of marriage? Column 2 of Table 4 tests this hypothesis by including the age at first marriage as a control variable. The estimated reduced form coefficient in the male sub-sample is now 0.523 and statistically insignificant, whilst the equivalent coefficient continues to be statistically indistinguishable from zero in the female sub-sample. In other words, the law seems to have an insignificant impact on the age at first child once the timing of marriage is controlled for. In addition to this, both men and women on average have their first child approximately half a year after the first year of marriage. The same patterns are repeated in the remaining two columns in which the IV estimates are reported. We can see from Column 3 that the effect of compulsory schooling on the age at first child birth is positive and statistically significant only for men but not for women. However, the effect disappears once age at first marriage has been controlled for in the regression, which seems to be consistent with Coale's (1971) conclusion that age at first marriage is an important - if not the most important - determinant of fertility.

\section{Conclusions}

In the current study, we are able to show that the raising of the minimum school-leaving age from 14 to 15 in the UK in 1947 had led to a discontinuity in the timing of first marriage for 
cohorts born from April $1^{\text {st }} 1933$, i.e. those who were aged 14 from April $1^{\text {st }} 1947$ onward and were therefore exposed to the law. The positive reduced form effect, which is statistically more robust for men than for women, is consistent with the institutional effects of education on age at first marriage in which people tend to delay marriage while attaining educational qualifications (see, e.g., Matsushita, 1989; Brüderl \& Diekman, 1997). The LATEs are sizeable; one more year spent at school caused the average age at first marriage to rise by approximately 3 to 3.4 years for men and 1.3 to 2 years for women. For men, the LATE is also noticeably larger than the average effect of 0.8 year produced by OLS. This indicates the presence of a large and negative bias in the observed cross-section correlation between schooling and age at first marriage, which could have been caused by the fact that schooling was continuously on the rise even before the start of the war, while the age at first marriage was on the fall immediately after the war had ended. Given the compelling effect of the 1947 reform, which affected about a half of the relevant population, it is likely that our RD and IV estimates of the schooling effect on age at first marriage come close to mirroring the ATE for the general population in the UK (Oreopoulos, 2006).

How do our results fit into the literature? For a start, whilst most studies focused mainly on the estimation of the causal effect of female education on the timing of marriage (Skirbekk et al., 2004; Kirdar et al., 2009), we actually find the delaying effect to be present for the compliers of the law of both genders. This should be of some interest to social scientists and policy makers, given the evidence that early marriage is beneficial to men's health but may have an adverse effect on their marital stability. The LATE of both men's and women's schooling is larger than one; for instance, a one-year increase in schooling resulted in men delaying their first marriage by approximately three years. One possible explanation for this huge effect is that, according to the enrolment model, an extra year spent at school may result in a three-year delay in the timing of first marriage provided that it also increases 
the probability of individuals holding an academic credential (for example, a university degree takes three years to complete in the UK). However, like Devereux and Hart (2010), we have tested this empirically using the BHPS and found no evidence of any effects of the law change on the probability of individuals of either gender obtaining an academic credential of at least at the pre-university level, e.g., O-levels. This suggests that there may be some underlying reasons other than the institutional effect that led both men and women to put off their first marriage to a later date. In any case, our study of the change in the minimum school-leaving age law provides contradictive evidence to Becker's idea that an increase in human capital should at least lead to an early marriage for men. 


\section{Reference}

Adams, Scott J. 2002. Educational attainment and health: Evidence from a sample of older adults. Education Economics, 10, 97-109.

Angrist, Joshua D., and Kruger, Alan B. 2001. Instrumental variables and the search for identification: From supply to demand and natural experiments. Journal of Economic Perspectives, 15(4), 69-85.

Becker, Gary S. 1973. A theory of marriage: part I. Journal of Political Economy, 81, 813846.

Blackburn, McKinley L., and Neumark, David. 1995. Are OLS estimates of the return to schooling biased downward? Another look. Review of Economics and Statistics, 77(2), 217229.

Breierova, Lucia and Esther Duflo. 2004. The impact of education on fertility and child mortality: Do fathers really matter less than mothers? NBER Working Paper \#10513.

Brüderl, Josef and Andreas Diekman. 1997. Education and marriage: a comparative study. Department of Sociology: Mannheim University, mimeo.

Card, David. 2001. Estimating the return to schooling: Progress on some persistent econometric problems. Econometrica, 69, 1127-1160.

Clark, Damon, and Royer, Heather. 2008. The effect of education on adult mortality and health: evidence from the United Kingdom. Department of Economics: Dartmouth University, manuscript.

Coale, Ansley J. 1971. Age patterns of marriage. Population Studies, 25, 193-214. 
Devereux, Paul and Gautam Tripathi. 2009. Optimally combining censored and uncensored datasets. Journal of Econometrics, 151, 17-32.

Devereux, Paul J., and Hart, Robert A. 2010. Forced to be rich? Returns to compulsory schooling in Britain. Economic Journal, forthcoming.

Ermisch, John. 2003. An economic analysis of the family. Princeton University Press.

Fan, Jianqing and Irene Gijbels. 1992. Variable bandwidth and local linear regression smoothers. The Annals of Statistics, 20(4), 2008-2036.

Field, Erica and Attila Ambrus. 2008. Early marriage, age of menarche, and female schooling attainment in Bangladesh. Journal of Political Economy, 116, 881-930.

Gardner, Jonathan and Andrew J. Oswald. 2004. How is mortality affected by money, marriage, and stress? Journal of Health Economics, 23, 1181-1207.

Glick, Paul C. 1977. Updating the life cycle of the family. Journal of Marriage and Family, $39,5-13$.

Goldstein, Joshua R. and Catherine T. Kenney. 2001. Marriage delayed and marriage foregone? New cohort forecasts of first marriage for U.S. women. American Sociological Review, 66, 506-519.

Harmon, Colm, and Ian Walker. 1995. Estimates of the return to schooling for the United Kingdom. American Economic Review, 85(5), 1278-1286.

Imbens, Guido W., and Angrist, Joshua D. 1994. Identification and estimation of local average treatment effects. Econometrica, 62(2), 467-475.

Imbens, Guido W., and Thomas Lemieux. 2008. Regression discontinuity designs: a guide to practice. Journal of Econometrics, 142, 615-635. 
Isen, Adam and Betsey Stevenson. 2010. Women's Education and Family Behavior: Trends in Marriage, Divorce and Fertility. NBER Working Paper No. 15725.

Jürges, Hendrik ; Kruk, Eberhard, and Reinhold, Steffen. 2010. The effect of compulsory schooling on health: evidence from biomarkers. MEA Discussion Paper 183-09.

Keeley, Michael. 1979. An analysis of the age pattern at first marriage. International Economic Review, 20, 527-544.

Kırdar, Murat, Meltem Dayığlu Tayfur, and İsmet Koç. 2009. The impact of schooling on the timing of marriage and fertility: evidence from a change in compulsory schooling law. MPRA Discussion Paper \#13410.

Koball, Heather. 1998. Have African American men become less committed to marriage? Explaining the twentieth century racial cross-over in men's marriage timing. Demography, $35,251-258$.

Korenman, Sanders and David Neumark. 1991. Does marriage really make men more productive? Journal of Human Resources, 26, 282-307.

Korenman, Sanders and David Neumark. 1992. Marriage, motherhood, and wages. Journal of Human Resources, 27, 233-255.

Klaauw, Wilbert van der. 1996. Female labor supply and marital status decision. Review of Economics Studies, 63, 199-235.

Lleras-Muney, Adriana. 2005. The relationship between education and adult mortality in the United States. Review of Economics Studies, 72, 189-221.

Loe, Eng Seng. 1996. Productivity differences and the marriage wage premium for white males. Journal of Human Resources, 31, 566-589. 
Martin, Teresa Castro, and Larry L. Bumpass. 1989. Recent trends in marital disruption. Demography, 26, 37-51.

Matsushita, Keiichiro. 1989. Economic analysis of age at first marriage. Journal of Population Economics, 2, 103-119.

Moore, Kristin, and Linda Waite. 1981. Marital dissolution, early motherhood and early marriage. Social Forces, 60, 20-40.

Oppenheimer, Valerie K. 1997. Women's employment and the gain to marriage: The specialization and trading model. Annual Review of Sociology, 23, 431-453.

Oreopoulos, Philip. 2006. Estimating local and average treatment effects when compulsory schooling really matter. American Economic Review, 96(1), 152-175.

Oreopoulos, Philip. 2007. Do dropouts drop out too soon? Wealth, health and happiness from compulsory schooling. Journal of Public Economics, 91(11-12), 2213-2229.

Ozer, Daniel J. and Verónica Benet-Martínez. 2006. Personality and the prediction of consequential outcomes. Annual Review of Psychology, 57, 401-421.

Powdthavee, Nattavudh. 2009. I can’t smile without you: spousal correlation in life satisfaction. Journal of Economic Psychology, 30, 675-689.

Powdthavee, Nattavudh. 2010. Does education reduce the risk of hypertension? Estimating the biomarker effect of compulsory schooling in England. IZA Working Paper \#4847.

Raymo, James. 2003. Educational Attainment and the Transition to First Marriage Among Japanese Women. Demography, 40, 83-103.

Silles, Mary A. 2009. The causal effect of education on health: evidence from the United Kingdom. Economics of Education Review, 28, 122-128. 
Skirbekk, Vegard, Hans-Peter Kohler, and Alexia Prskawetz. 2004. Birth months, school graduation, and the timing of birth and marriages. Demography, 41, 547-568.

Spasojevic, Jelena. 2003. Effects of education on adult health in Sweden: Results from a natural experiment. PhD Dissertation, City University of New York Graduate Center, New York.

Taylor, Marcia F.; John Brice; Nick Buck; and Elaine Prentice-Lane. 2002. British Household Panel Survey User Manual. Colchester: University of Essex.

Thornton, Arland, William G. Axinn and Jay D. Teachman. 1995. The Influence of School Enrollment and Accumulation on Cohabitation and Marriage in Early Adulthood. American Sociological Review, 60: 762-774.

Wallace, R.G. 1981. The origins and authorship of the 1944 education act. History of Education, 10, 283-290.

Wong, Odalia M.H. 2005. The socioeconomic determinants of the age at first marriage among women in Hong Kong. Journal of Family and Economic Issues, 26, 529-550.

Worner, Shane. 2005. Marriage and Education in Australia: Decomposing the Enrolment and Human Capital Effects. The Australian National University, Centre for Economic Policy Research Discussion Paper \#550. 


\section{4 (MALE SAMPLE)}

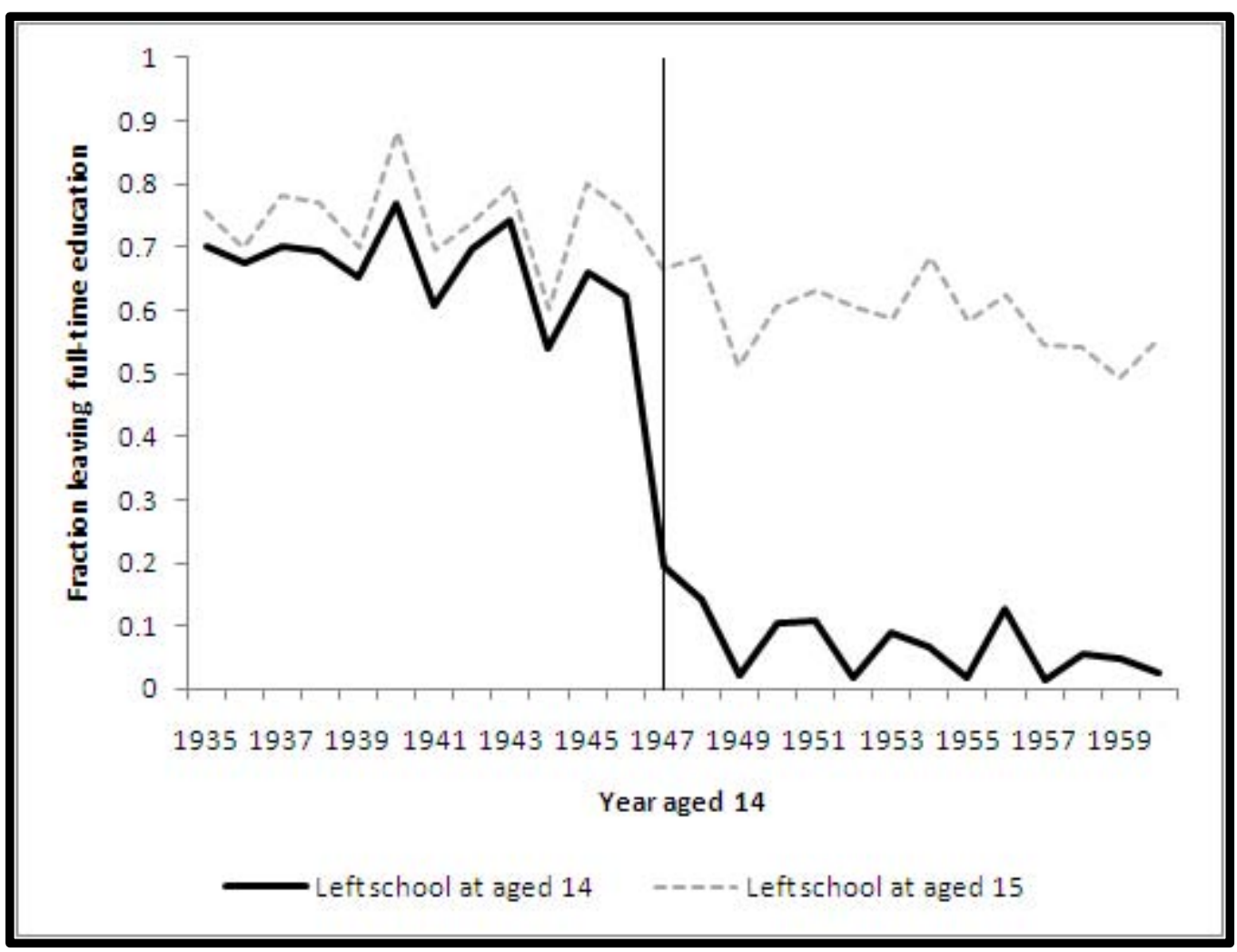

Note: the bottom line represents the proportion of men in the BHPS who left school at or before the age of 14 between 1940 and 1953, and the top is the same but for age 15 . Note that the first introduction of minimum school-leaving age law in the United Kingdom took place in 1947 (from age 14 to 15), as indicated by the vertical lines. 


\section{4 (FEMALE SAMPLE)}

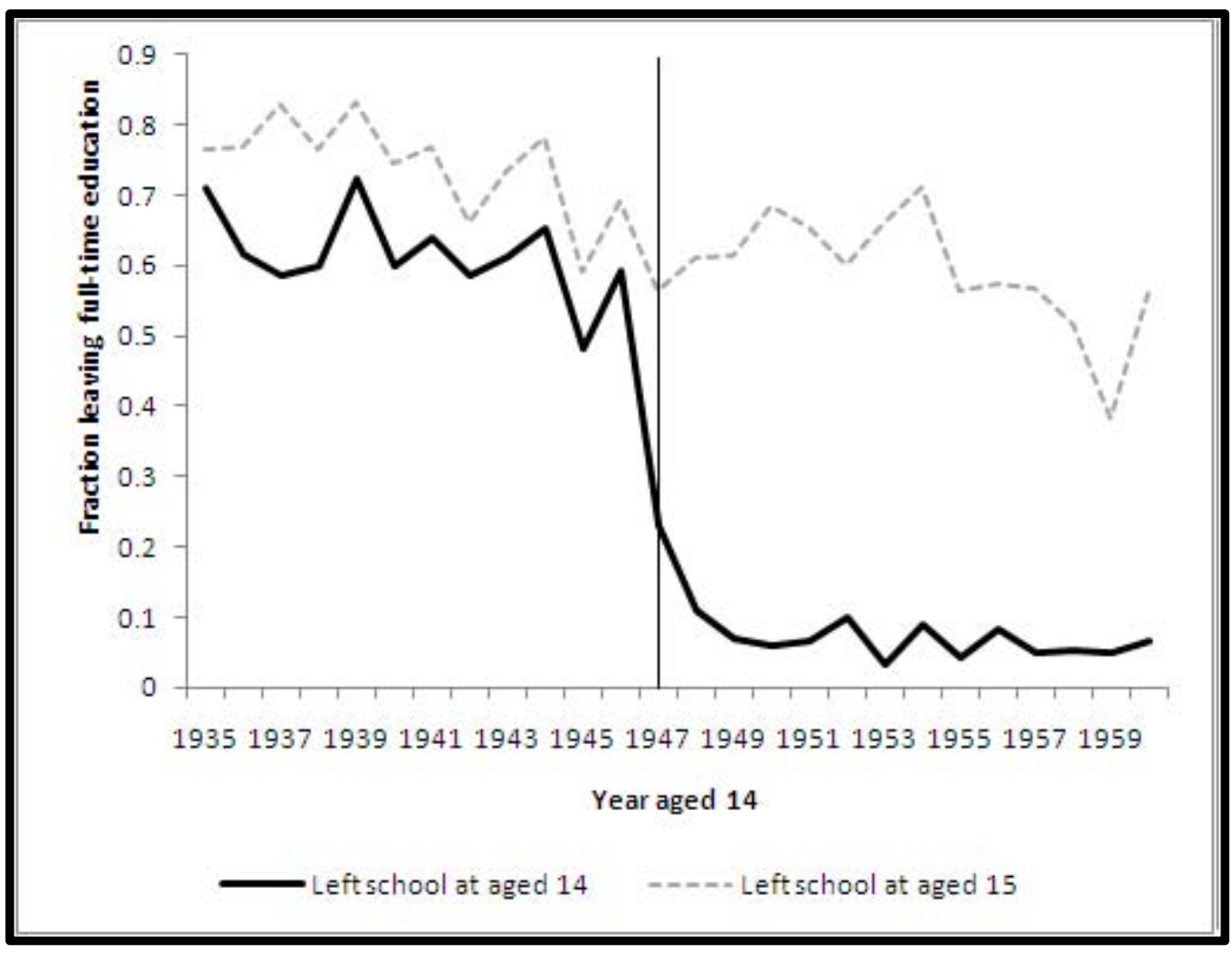

Note: the bottom line represents the proportion of men in the BHPS who left school at or before the age of 14 between 1940 and 1953, and the top is the same but for age 15 . Note that the first introduction of minimum school-leaving age law in the United Kingdom took place in 1947 (from age 14 to 15), as indicated by the vertical lines. 
TABLE 1: OLS ESTIMATES ON THE CORRELATION BETWEEN SCHOOLING

\section{AND AGE AT FIRST MARRIAGE IN THE UK (COHORTS 1921-1946)}

\begin{tabular}{lcc}
\hline & Male & Female \\
& $(\mathrm{N}=1,219)$ & $(\mathrm{N}=1,441)$ \\
\hline Schooling & 0.759 & 0.987 \\
& $(0.114)^{* *}$ & $(0.107)^{* *}$ \\
\hline
\end{tabular}

Note: $* *<1 \%$. The data source is Wave 2, BHPS. Regression equations control for a quartic function of birth year and allow for clustering by birth year. Standard errors are in parentheses. 
TABLE 2: ESTIMATED EFFECTS OF THE 1947 COMPULSORY SCHOOLING

\section{LAW ON AGE AT FIRST MARRIAGE IN THE UK}

\begin{tabular}{|c|c|c|c|c|}
\hline & & $\begin{array}{l}\text { First- } \\
\text { stage }\end{array}$ & $\begin{array}{c}\text { Reduced } \\
\text { form }\end{array}$ & IV \\
\hline & & (1) & (2) & (3) \\
\hline \multirow[t]{3}{*}{ Men } & Law change in $1947=1$ & $\begin{array}{c}0.746 \\
(0.152)^{* *}\end{array}$ & $\begin{array}{c}2.565 \\
(0.645)^{* *}\end{array}$ & \\
\hline & Schooling & & & 3.440 \\
\hline & $($ Instrument: Law change $=1)$ & & & $(0.823)^{* *}$ \\
\hline \multirow[t]{3}{*}{ Women } & Law change in $1947=1$ & $\begin{array}{c}0.526 \\
(0.101)^{* *}\end{array}$ & $\begin{array}{l}0.683 \\
(0.470)\end{array}$ & \\
\hline & Schooling & & & 1.298 \\
\hline & $($ Instrument: Law change $=1)$ & & & $(0.715)+$ \\
\hline
\end{tabular}

Note: $+<10 \%, * *<1 \%$. Men: $\mathrm{N}=1,219$. Women: $\mathrm{N}=1,441$. All regressions include a quartic function of birth year as controls. Standard errors are in parentheses and are robust to clustering by birth year. 


\section{FIGURE 3: LOCAL AVERAGES AND PARAMETRIC FIT OF AVERAGE}

\section{SCHOOLING AGE BY YEAR AGED 14 (MALE SAMPLE)}

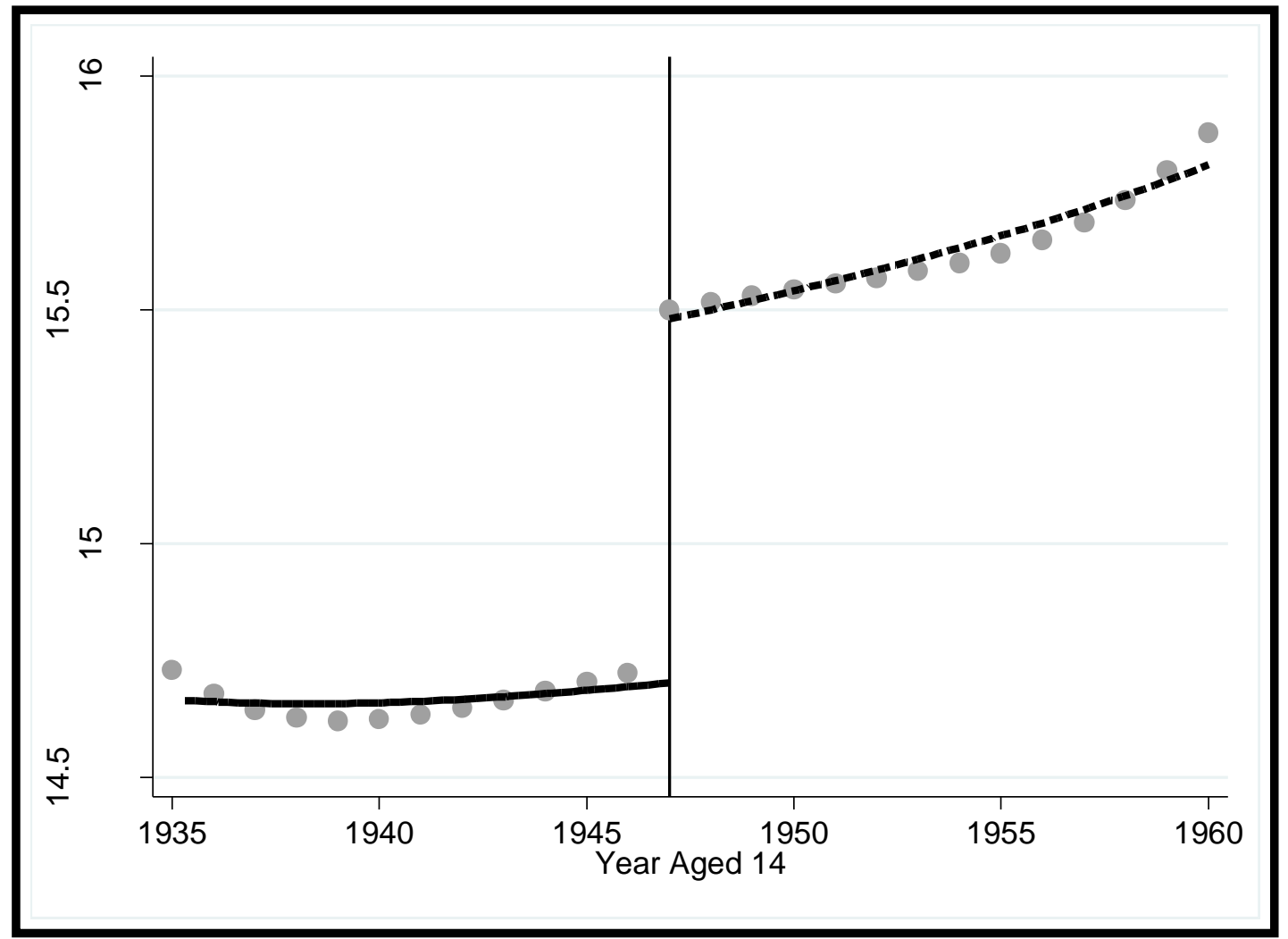

Note: Local averages are plotted for English individuals who were aged 14 between 1935 and 1960. The line represents the predicted fit by regressing mean age finished full-time education on a quartic function of birth year and an indicator for the school leaving age faced at 14 . The circles represent local averages by birth year. The minimum school-leaving age was raised from age 14 to 15 in 1947 , as indicated by the vertical line. 


\section{FIGURE 4: LOCAL AVERAGES AND PARAMETRIC FIT OF AVERAGE}

\section{SCHOOLING AGE BY YEAR AGED 14 (FEMALE SAMPLE)}

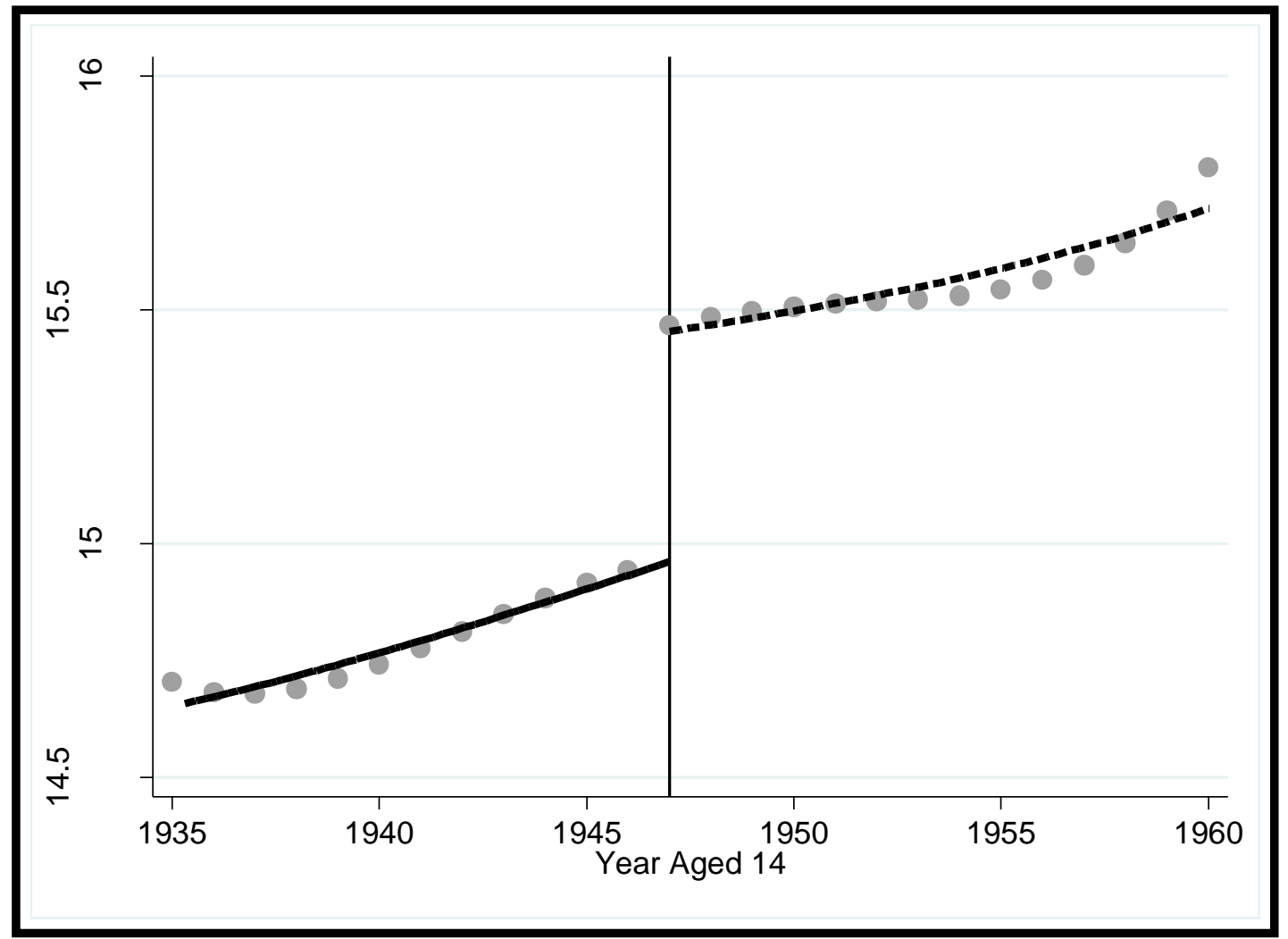

Note: Local averages are plotted for English individuals who were aged 14 between 1935 and 1960. The line represents the predicted fit by regressing mean age finished full-time education on a quartic function of birth year and an indicator for the school leaving age faced at 14 . The circles represent local averages by birth year. The minimum school-leaving age was raised from age 14 to 15 in 1947, as indicated by the vertical line. 


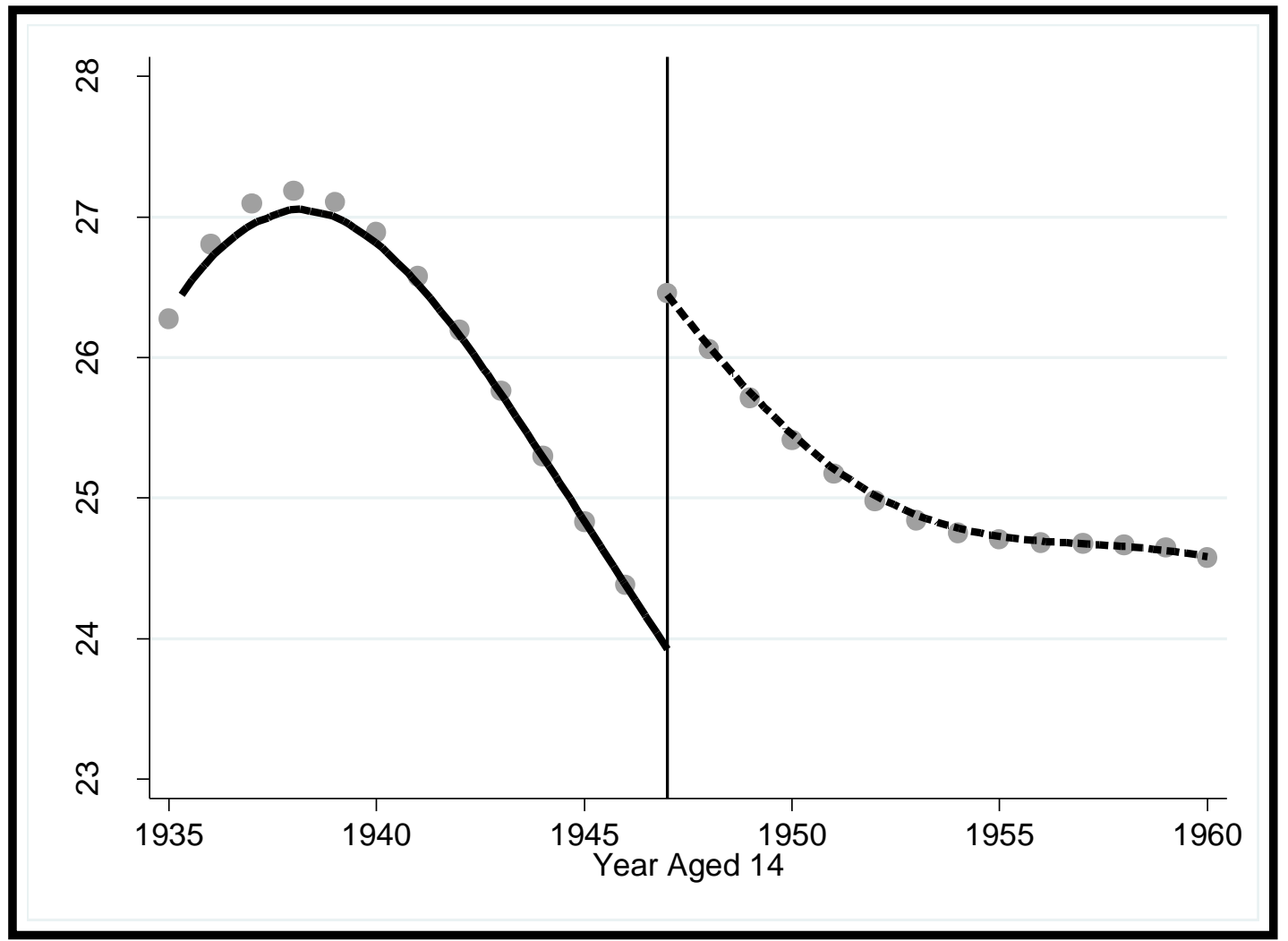

Note: Local averages are plotted for English individuals who were aged 14 between 1935 and 1960. The line represents the predicted fit by regressing mean age finished full-time education on a quartic function of birth year and an indicator for the school leaving age faced at 14 . The circles represent local averages by birth year. The minimum school-leaving age was raised from age 14 to 15 in 1947, as indicated by the vertical line. 


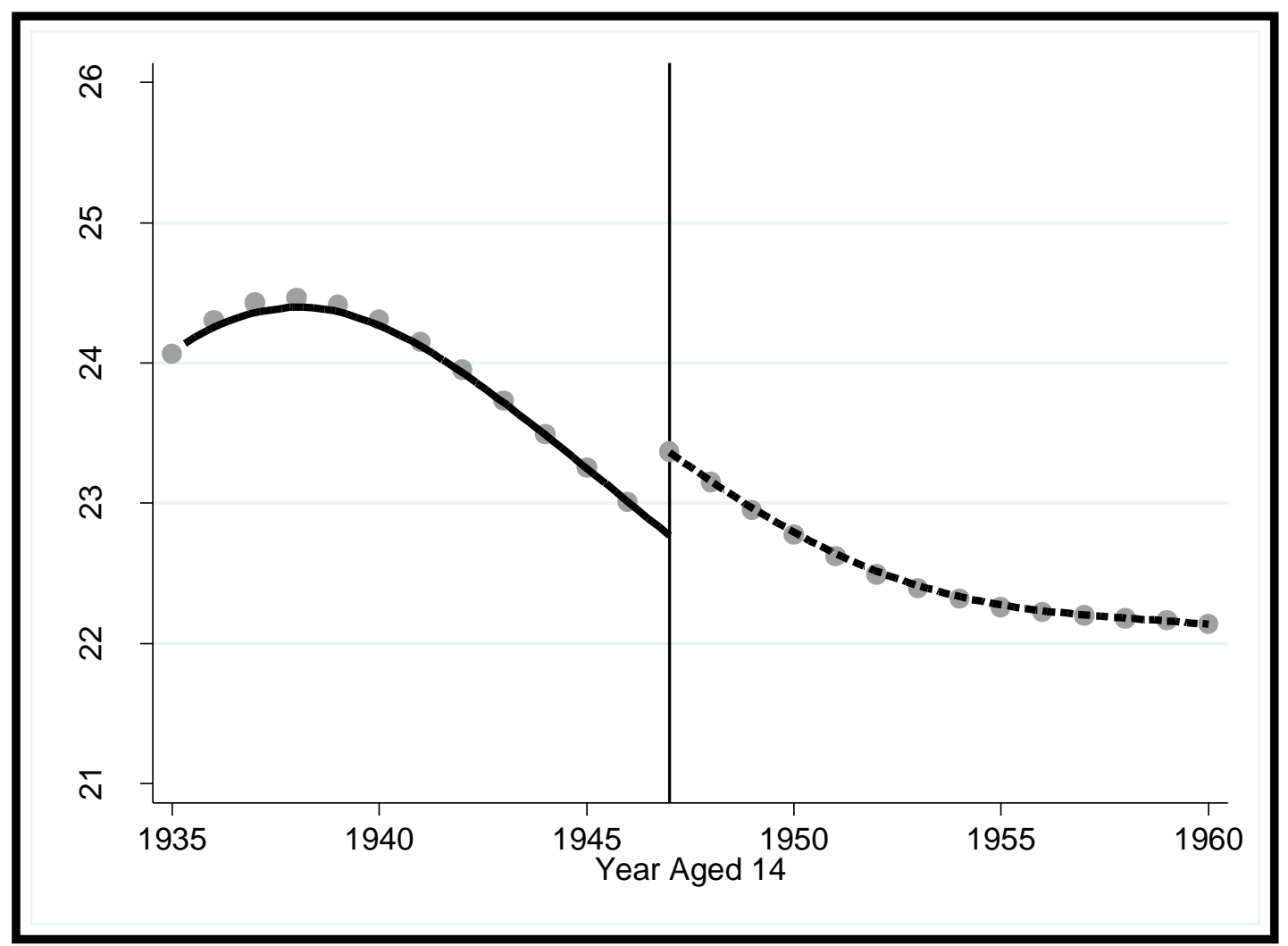

Note: Local averages are plotted for English individuals who were aged 14 between 1935 and 1960. The line represents the predicted fit by regressing mean age finished full-time education on a quartic function of birth year and an indicator for the school leaving age faced at 14 . The circles represent local averages by birth year. The minimum school-leaving age was raised from age 14 to 15 in 1947 , as indicated by the vertical line. 
TABLE 3: RESTRICT SAMPLE TO COHORTS 1926-1939

\begin{tabular}{lccc}
\hline & & First- & Reduced \\
& stage & form \\
\cline { 3 - 4 } & & $(1)$ & $(2)$ \\
\hline Men & Law change in $1947=1$ & 0.587 & 1.743 \\
& & $(0.160)^{* *}$ & $(0.716)^{*}$ \\
\hline Women & Law change in $1947=1$ & 0.684 & 1.385 \\
& & $(0.093)^{* *}$ & $(0.404)^{* *}$ \\
\hline
\end{tabular}

Note: $* *<1 \%, *<5 \%$. Men: $\mathrm{N}=613$; Women: $\mathrm{N}=681$. All regressions include a quartic function of birth year as controls. Standard errors are in parentheses and are robust to clustering by birth year. 
TABLE 4: ESTIMATED EFFECTS OF EDUCATION ON AGE AT THE BIRTH OF FIRST CHILD CONDITIONING ON MARRIAGE

\begin{tabular}{|c|c|c|c|c|c|}
\hline & & Reduce & d-form & & $\bar{V}$ \\
\hline & & (1) & (2) & (3) & (4) \\
\hline Men & Law change in $1947=1$ & $\begin{array}{c}1.834 \\
(0.938)+\end{array}$ & $\begin{array}{l}0.523 \\
(0.617)\end{array}$ & & \\
\hline & $\begin{array}{l}\text { Schooling } \\
\text { (Instrument: Law change }=1)\end{array}$ & & & $\begin{array}{c}2.594 \\
(1.261)^{*}\end{array}$ & $\begin{array}{l}0.589 \\
(1.133)\end{array}$ \\
\hline & Age of $1^{\text {st }}$ marriage & & 0.775 & & 0.738 \\
\hline & & & $(0.062)^{* *}$ & & $(0.083)^{* *}$ \\
\hline Women & Law change in $1947=1$ & $\begin{array}{l}0.670 \\
(0.723)\end{array}$ & $\begin{array}{l}0.707 \\
(0.532)\end{array}$ & & \\
\hline & Schooling & & & 1.922 & 1.821 \\
\hline & (Instrument: Law change $=1$ ) & & & $(1.689)$ & $(1.350)$ \\
\hline & Age of $1^{\text {st }}$ marriage & & 0.784 & & 0.632 \\
\hline & & & $(0.063)^{* *}$ & & $(0.133)^{* *}$ \\
\hline
\end{tabular}

Note: $* *<1 \%, *<5 \%,+<10 \%$. Men: $\mathrm{N}=1,073$, Women: $\mathrm{N}=1,278$. For control variables, see Table 2. 
TABLE A1: DESCRIPTIVE STATISTICS (BHPS: COHORTS 1921-1946)

\begin{tabular}{lcccccc}
\hline \multirow{2}{*}{ Men } & \multicolumn{2}{c}{ All } & \multicolumn{2}{c}{ Left school at 14 } & Left school at 15 \\
\cline { 2 - 7 } & M & SD & M & SD & M & SD \\
\hline Age at first marriage & 25.46 & 4.94 & 26.16 & 5.44 & 25.01 & 4.54 \\
Age finished full-time education & 15.25 & 1.34 & 14.67 & 1.27 & 15.64 & 1.25 \\
Minimum school-leaving age $=15$ & 0.59 & 0.49 & - & - & - & - \\
Age & 56.83 & 7.61 & 64.87 & 3.51 & 51.41 & 3.97 \\
\hline Women & M & SD & M & SD & M & SD \\
\hline Age at first marriage & 23.05 & 4.70 & 23.92 & 5.37 & 22.43 & 4.06 \\
Age finished full-time education & 15.25 & 1.31 & 14.78 & 1.28 & 15.58 & 1.23 \\
Minimum school-leaving age $=15$ & 0.58 & 0.49 & - & - & - & - \\
Age & 57.10 & 7.85 & 65.14 & 3.59 & 51.26 & 4.00 \\
\hline
\end{tabular}

